\title{
Antibacterial activity of Veronica montana $L$. extract and of protocatechuic acid incorporated in a food system
}

Dejan S. Stojkovića , Jelena Živković ${ }^{b}$, Marina Sokovića ${ }^{a}$ Jasmina Glamočlija ${ }^{\mathrm{a}}$, Isabel C.F.R.

$$
\text { Ferreira }^{\mathrm{c}, *}, \text { Teodora Janković }{ }^{\mathrm{b}}, \text { Zoran Maksimović }^{\mathrm{d}}
$$

aniversity of Belgrade, Institute for Biological Research "Siniša Stankovič”, Department of Plant Physiology, Bulevar Despota Stefana 142, 11000 Belgrade, Serbia.

'Institute for Medicinal Plant Research "Dr. Josif Pančić”, Tadeuša Košćuška 1, 11000 Belgrade, Serbia.

${ }^{\mathrm{C}}$ CIMO-ESA, Polytechnic Institute of Bragança, Campus de Santa Apolónia, Ap. 1172, 5301-855 Bragança, Portugal.

${ }^{\mathrm{d}}$ University of Belgrade, Faculty of Pharmacy, Department of Pharmacognosy, Vojvode Stepe 450, 11221 Belgrade, Serbia.

*Author to whom correspondence should be addressed: (e-mail: iferreira@ipb.pt, telephone $+351-273-303219$, fax $+351-273-325405)$ 


\begin{abstract}
This study was designed to evaluate the antibacterial activity of the Veronica montana L. water extract and its main phenolic compound, protocatechuic acid. The antibacterial activity was determined by microdilution assay against six strains of Gram-positive and Gram-negative bacteria. Listeria monocytogenes was the most sensitive of the tested bacterial species. Antibacterial preserving properties of protocatechuic acid were also evaluated after its incorporation in cream cheese, using L. monocytogenes as commonly cheese contaminant. The compound successfully inhibited L. monocytogenes development in cream cheese, at room temperature and in refrigerator $\left(25^{\circ} \mathrm{C}\right.$ and $4{ }^{\circ} \mathrm{C}$, respectively), after 3 days of inoculation. Sensory evaluation was carried out in order to validate the mentioned food system. A possible mode of action of the tested compound towards bacterial cells was assessed and appears to be direct lysis of pathogenic cytoplasmic membrane. Prediction of pharmacokinetic properties was also performed using computational analyzes. The obtained results can serve as an important platform for the development of effective natural preservatives.
\end{abstract}

Keywords: Veronica montana; Protocatechuic acid; Antibacterial activity; Listeria monocytogenes; Cream cheese preservation; Sensory evaluation. 


\section{Introduction}

Foodborne diseases, which are provoked by food pathogenic bacteria and fungi, are of major concern in developing as well as developed countries (Mead et al., 1999). Therefore, chemical preservatives have been extensively used in the food industry to prevent the growth of food spoiling microbes (Natta et al., 2008). Nevertheless, due to potential harmful effects of synthetic

chemicals, there is a pressure for progressive substitution of chemical preservatives and adoption of natural alternatives to obtain microbial safety of food. This resulted in increasing search for new technologies to be used in food conservation systems, which include alternative antimicrobial compounds or combination of conventional (used in low levels) and alternative ones (Brull and Coote, 1999). Natural extracts, essential oils and other isolated compounds with notable antimicrobial activity could be used to delay or inhibit the growth of pathogenic and/or toxin producing microorganisms in food (Reis et al., 2012; Tiwari et al. 2009). Originally, spices and herbs were added to change or to improve food taste. Today we know that plant antimicrobials are important in plant physiology because they contribute for resistance to microorganisms (Kim et al., 2001). It has been shown that polyphenols from different plant sources have interesting properties for the control of pathogens with relevance to humans (Cowan, 1999; Scalbert, 1991).

As currently circumscribed, Veronica (Plantaginaceae) is a genus of 450 plant species found in temperate regions of both hemispheres (Muñoz-Centeno et al., 2007). Numerous studies on the identification of secondary metabolites in Veronica species have already been published, being iridoid glucosides, phenylethanoid and flavonoid glycosides mainly reported (Taskova et al., 2010; Harput et al., 2011). In addition to the chemotaxonomic and phytochemical importance of the genus, Veronica species have become prominent due to their traditional uses and biological 
activities. Some of Veronica species are used mostly as diuretics and for their wound-healing properties in traditional Turkish medicine. According to Chinese tradition, Veronica species are used as restoratives, tonics, in medical treatment of influenza and other respiratory diseases (Harput et al., 2011), and by Native Americans as an expectorants to alleviate bronchial congestion associated with asthma and allergies (Tilford, 1997). Extracts obtained from aboveground parts of various Veronica species are used as folk remedies for treatment of various inflammatory ailments, including rheumatism (Küpeli et al., 2005). In addition, stems and leaves of some Veronica species are edible, either raw or cooked (Hong, 1998).

Some Veronica species were already investigated for their antimicrobial activities using discdiffusion method (Abu Ziada et al., 2008; Condrat et al., 2009; Dulger and Ugurlu, 2005). However, as far as we know, this is the first study on antimicrobial effects of Veronica montana, exploring the incorporation of its bioactive compound in a food system. It was aimed to explore antimicrobial activity of $V$. montana water extract and of its main phenolic compound, protocatechuic acid. Antibacterial preserving properties of protocatechuic acid were further evaluated after its incorporation in cream cheese contaminated with Listeria monocytogenes. The antimicrobial mode of action of protocatechuic acid towards L. monocytogenes cells, as its computational pharmacokinetic profile, were also studied.

\section{Material and Methods}

\subsection{Plant material and extract preparation}

The aerial parts of Veronica montana were collected during the flowering period, from mountain Goč in central Serbia. Plant material was taxonomically classified and the voucher specimen (accession number VmZ08) was deposited in the Herbarium collection of the Institute of Botany, 
Faculty of Pharmacy, University of Belgrade. The air-dried plant material was reduced to a fine powder and extracted by maceration method using water as solvent $(1: 20, \mathrm{w} / \mathrm{v})$, at room temperature for 48h. The extract was then lyophilized (LH Leybold, Lyovac GT2, Frenkendorf, Switzerland) and stored in dark at $4{ }^{\circ} \mathrm{C}$ until further tests.

\subsection{Chemical characterization of the extract regarding phenolic compounds}

Water extract of $V$. montana was dissolved in methanol $(20 \mathrm{mg} / \mathrm{ml})$, prior to HPLC analysis. Analysis was carried out on an Agilent 1200 RR system with diode array detector. Detection wavelengths were set at 204, 270 and $330 \mathrm{~nm}$. The separation was achieved using an Agilent Zorbax SB-C18 column $(150 \mathrm{~mm} \times 4.6 \mathrm{~mm}, 5 \mu \mathrm{m})$ with a flow rate $1 \mathrm{ml} / \mathrm{min}$. The injection volume was $5 \mu 1$ and the column temperature was maintained at $25^{\circ} \mathrm{C}$. Mobile phase consisted of solvent A ( $1 \% v / v$ solution of orthophosphoric acid in water) and solvent B (acetonitrile) using the gradient elution as follows: $98-90 \%$ A $0-5 \mathrm{~min}, 90-85 \%$ A $5-10 \mathrm{~min}, 85 \%$ A $10-30 \mathrm{~min}, 85-$ $82 \%$ A $30-32 \mathrm{~min}, 82 \%$ A $32-42 \mathrm{~min}, 82-75 \%$ A $42-50 \mathrm{~min}, 75-60 \%$ A $50-55 \mathrm{~min}, 60-30 \%$ A 55-60 min, 30-0\% A 60-63 min, 0\% A 63-65 min. Peak identification in HPLC analysis was performed by comparison of retention time and UV spectra of reference standard protocatechuic acid. Quantification was achieved by the absorbance recorded in the chromatogram relative to external standard, with detection at $204 \mathrm{~nm}$. Protocatechuic acid was purchased from Extrasynthese (Genay, France).

\subsection{Microorganisms and culture conditions}


For the bioassays seven bacterial strains were used, four Gram-positive: Staphylococcus aureus (ATCC 6538), Bacillus cereus (human isolate), Micrococcus flavus (ATCC 10240) and Listeria monocytogenes (NCTC 7973), and three Gram-negative: Pseudomonas aeruginosa (ATCC 27853), Enterobacter cloacae (human isolate) and Escherichia coli (ATCC 35210).

All of the tested microorganisms were obtained from the Department of Plant Physiology, Institute for Biological Research "Siniša Stanković", Belgrade, University of Belgrade, Serbia. The bacteria were cultured on Mueller-Hinton agar $(\mathrm{MH})$ and cultures were stored at $+4{ }^{\circ} \mathrm{C}$ and subcultured once a month.

\subsection{Microdilution method}

The modified microdilution technique was used to evaluate antimicrobial activity (Hanel and Raether 1998). Bacterial species were cultured overnight at $37^{\circ} \mathrm{C}$ in Tryptic Soy Broth (TSB) medium. The bacterial cell suspensions were adjusted with sterile saline to a concentration of approximately $1.0 \times 10^{6}$ in a final volume of $100 \mu \mathrm{l}$ per well. The inocula were stored at $+4{ }^{\circ} \mathrm{C}$ for further use. Dilutions of the inocula were cultured on solid Múller-Hinton (MH) for bacteria to verify the absence of contamination and to check the validity of the inoculum. Determination of minimum inhibitory concentrations (MICs) was performed by a serial dilution technique using 96-well microtitre plates. Both tested samples (extract and the phenolic acid) were dissolved in $5 \%$ solution of dimethyl sulfoxide (DMSO) and added to broth TSB medium with inoculum. The microplates were incubated for $48 \mathrm{~h}$ at $37^{\circ} \mathrm{C}$. The lowest concentrations without visible growth (at the binocular microscope) were defined as MICs. The minimum bactericidal concentrations (MBCs) were determined by serial subcultivation of a $2 \mu$ into microtitre plates containing 100 
$\mu \mathrm{l}$ of broth per well and further incubation for $48 \mathrm{~h}$ at $37^{\circ} \mathrm{C}$. The lowest concentration with no visible growth was defined as MBC, indicating 99.5\% killing of the original inoculum.

Streptomycin (Sigma P 7794) $(0.05-3 \mathrm{mg} / \mathrm{ml})$ was used as positive control for bacterial growth. A $5 \%$ solution of DMSO in water was used as negative control.

\subsection{Cream cheese}

Full-fat cream cheese (“a la Kajmak”, Mlekara Šabac) was purchased from a local supermarket and kept in refrigerator at $4^{\circ} \mathrm{C}$ until further analyzes. All the samples of cream cheese were used before expiring date of the product. Composition of the cream cheese stated on the label was: energy, $242 \mathrm{kcal}$; fat, $23.5 \mathrm{~g}$; proteins, $6.1 \mathrm{~g}$ and lactose, $1.1 \mathrm{~g}$, all values expressed by $100 \mathrm{~g}$. No artificial preservatives were mentioned in the label, but it included the recommendation of using in 3 days after opening, at $0^{\circ} \mathrm{C}-8^{\circ} \mathrm{C}$. Experiments of inoculating Malt Agar (MA) and MullerHinton Agar (MHA) plates with cheese diluted in phosphate buffered saline (PBS; 1:10, v/v) and kept at 25 and $37^{\circ} \mathrm{C}$, for $48 \mathrm{~h}$, showed neither bacterial nor fungal contamination of the product.

\subsection{In situ antibacterial assay in cream cheese food system}

The modified method that was previously described by Reis et al. (2012) was used to assess antibacterial activity of protocatechuic acid in cream cheese. Briefly, $10 \mathrm{~g}$ of cream cheese were added to $90 \mathrm{ml}$ of PBS in sterile flasks and homogenized for $2 \mathrm{~min}$. Protocatechuic acid was added to the cheese mixture to achieve final concentrations of $0.75,1.5$ and $3.0 \mathrm{mg} / \mathrm{ml}$. The controls contained L. monocytogenes in cream cheese diluted with PBS but not protocatechuic 
acid. The flasks were homogenized for $30 \mathrm{~s}$ to ensure the mixture of protocatechuic acid with cream cheese dilution.

The cheese mixture was inoculated with $\sim 10^{6}$ cell units $(\mathrm{CU})$ of Listeria monocytogenes. The inoculum was mixed thoroughly with the cheese mixture by hands and the concentration of Listeria monocytogenes cells was determined in the cheese at $0,24,48$ and $72 \mathrm{~h}$, using the serial dilution and spread plate technique (Jay, 1992). Experimental flasks were divided in two groups: one group was kept at $25{ }^{\circ} \mathrm{C}$ and the other at $4{ }^{\circ} \mathrm{C}$. Both groups contained equal amount of protocatechuic acid. PBS was used as the diluent and bacterium was cultured on solid MH plates at $37^{\circ} \mathrm{C}$ for $24 \mathrm{~h}$. The results were expressed as inhibition percentage of original inoculum.

\subsection{Sensory evaluation}

Sensory evaluation of cream cheese and of cream cheese incorporated with protocatechuic acid was assessed by a group of 10 untrained panelists. Panelists were selected among students and staff of the Department of Plant Physiology (Mycological Laboratory). Their participation was voluntary and not rewarded. An informed consent form was completed prior to the sensory evaluation sessions. Cream cheese samples enriched with protocatechuic acid were prepared by adding the highest amount used in previous experiments ( $3 \mathrm{mg}$ to $1 \mathrm{ml}$ of cream cheese). The panelists were asked to evaluate overall acceptance of the food samples (cream cheese alone and cream cheese enriched with protocatechuic acid) on a scale from 5 to 1; indicating decreasing taste. A general taste score was calculated as the average of all grades. Overall acceptance was evaluated using a 5-point scale, according to a previous report (Sorheim et al., 1996), where $1=$ extremely dislike, 2 = dislike, $3=$ neither like nor dislike, $4=$ like; $5=$ extremely like. 


\subsection{Insights in the mode of antimicrobial action of protocatechuic acid}

The effect of protocatechuic acid in membrane permeability (nucleotide leakage) was evaluated according to Tang et al. (2008) with some modifications. The overnight culture of Listeria monocytogenes at $37^{\circ} \mathrm{C}$ was washed and resuspended in $10 \mathrm{mM}$ PBS (pH 7.4), reaching the final

density of $5 \times 10^{7} \mathrm{CU} / \mathrm{ml}$. Strain was incubated with the target molecule - protocatechuic acid at the $2 \times$ MIC for different time periods: 15, 30, 45, 60 and $90 \mathrm{~min}$; L. monocytogenes incubated with $10 \mathrm{mM}$ PBS (pH 7.4) was used as control. The mixture was filtered through $0.22 \mu \mathrm{m}$ pore size filter to remove the bacteria cells. The optical density of the filtrate was measured at $260 \mathrm{~nm}$ and $280 \mathrm{~nm}$ (Aglient 8453 spectrophotometer) at room temperature $\left(25^{\circ} \mathrm{C}\right)$.

\subsection{Computational analyzes of pharmacokinetic properties of protocatechuic acid}

The VolSurf programme (www.moldiscovery.com) was used to predict pharmacokinetic properties of the tested molecule. Caco- 2 cell permeability, plasma protein affinity, blood brain barrier (BBB) permeation and thermodynamic solubility of the studied compound were predicted.

\subsection{Statistical analysis}

All the experiments to evaluate antimicrobial activity were done in triplicate, repeated twice and expressed as mean values and standard deviation (SD). Results on sensory evaluation were expressed as average grades given by 10 panelists (mean values and SD). Statistical analysis of the results was done using Origin Pro 8 program. In order to analyze the sensory evaluation results the independent t-test with an alpha level of 0.05 was used. It was done to determine the 
differences in mean values of the variables between the scores of two samples (cream cheese alone and cream cheese enriched with protocatechuic acid).

\section{Results}

HPLC-DAD analysis indicated that the major polyphenol compound present in water extract of V. montana was protocatechuic acid (Figure 1). The concentration of this compound was 15.70 $\mathrm{mg} / \mathrm{g}$ extract.

The results of antibacterial activity of water extract, protocatechuic acid and standard antibiotic, tested by microdilution assay, are presented in Table 1. For the water extract of $V$. montana, the most prominent effect was achieved on Staphylococcus aureus with equal concentrations of MIC and $\mathrm{MBC}, 7.5 \mathrm{mg} / \mathrm{ml}$. The lowest inhibitory activity was noticed for Bacillus cereus and Pseudomonas aeruginosa $(22.5 \mathrm{mg} / \mathrm{ml})$, while MBC for both bacterial species was $45 \mathrm{mg} / \mathrm{ml}$. A medium sensitivity to V. montana water extract was recorded for Microccocus flavus (MIC 7.5 $\mathrm{mg} / \mathrm{ml}$ and MBC $15 \mathrm{mg} / \mathrm{ml}$ ), Listeria. monocytogenes (MIC $7.5 \mathrm{mg} / \mathrm{ml}$ and $\mathrm{MBC} 15 \mathrm{mg} / \mathrm{ml}$ ), Enterobacter cloacae (MIC $7.5 \mathrm{mg} / \mathrm{ml}$ and $\mathrm{MBC} 15 \mathrm{mg} / \mathrm{ml}$ ) and Eschericihia coli (MIC=MBC $15 \mathrm{mg} / \mathrm{ml}$ ). The extract activity in the tested pathogenic bacteria, decreased in order: S. aureus $>$ M. flavus $=$ L. monocyotegenes $=$ E. cloacae $>$ E. coli $>$ B. cereus $=$ P. aeruginosa .

The antibacterial potential of protocatechuic acid was similar against the majority of the tested bacteria. Minimum inhibitory and bactericidal concentrations were $3 \mathrm{mg} / \mathrm{ml}$, except for $L$. monocyotogenes which was the most susceptible species to the effect of protocatechuic acid (MIC $0.75 \mathrm{mg} / \mathrm{ml}$ and $\mathrm{MBC} 1 \mathrm{mg} / \mathrm{ml}$ ). Although, investigation on antimicrobial activity of protocatechuic acid showed similar MIC and MBC values, the same was not observed for the 
water extract. Thus, we may presume that other molecules present in crude water extract have possible synergistic antimicrobial effects with protocatechuic acid, expressing different target mechanisms on the bacterial species used.

Due to the in vitro sensitivity showed by L. monocytogenes, this species was chosen for further tests in cream cheese. The results obtained of in situ cream cheese preservation by protocatechuic acid are presented in Table 2. It is evident that higher concentrations had better antibacterial effect on L. monocytogenes growth inhibition. Concentrations of $3 \mathrm{mg} / \mathrm{ml}$ of protocatechuic acid in cream cheese kept at room temperature $\left(25^{\circ} \mathrm{C}\right)$ for 3 days had the same effect: $100 \%$ inhibition of L. monocytogenes growth in cheese. After that period, there were no cells of the contaminant tested that retained natural ability of cell division. Growth inhibition percentage was recorded after $24 \mathrm{~h}$ and $48 \mathrm{~h}$ from the beginning of experiment. Along storage, a gradual inhibition of L. monocytogenes was achieved at $1.5 \mathrm{mg} / \mathrm{ml}$. Concentrations of $0.75 \mathrm{mg} / \mathrm{ml}$ and $1.5 \mathrm{mg} / \mathrm{ml}$ had no effect at room temperature, after $72 \mathrm{~h}$. At $1.5 \mathrm{mg} / \mathrm{ml}$, the bacterium was inhibited after $24 \mathrm{~h}$, but after $48 \mathrm{~h}$, bacterium was able to overcome the effect of protocatechuic acid and concomitantly the inhibition percentage was lower. The growth of food-poisoning bacterium was inhibited $100 \%$ at the $3^{\text {rd }}$ day of experiment with $3 \mathrm{mg} / \mathrm{ml}$ of protocatechuic acid.

For the samples kept at $4{ }^{\circ} \mathrm{C}$ for 3 days, slightly different results were obtained. Growth inhibition percentage was higher than in the samples kept at $25^{\circ} \mathrm{C}$. Growth inhibition with all the tested concentrations $(0.75,1.5$ and $3 \mathrm{mg} / \mathrm{ml})$ was recorded after $24 \mathrm{~h}$ from the beginning of cream cheese storage at $4{ }^{\circ} \mathrm{C}$. Noticeable growth inhibition percentage was observed for all the tested samples, being in the range $94.34 \%-100.0 \%$, after $24 \mathrm{~h}$ from the beginning of inoculation. During the period of incubation, 1.5 and $3 \mathrm{mg} / \mathrm{ml}$ of protocatechuic acid inhibited $100 \% \mathrm{~L}$. 
monocytogenes growth at $4{ }^{\circ} \mathrm{C}$. Concentration of $0.75 \mathrm{mg} / \mathrm{ml}$ inhibited the bacterium tested, but cell survival was constant, neither decreasing, nor increasing after $24 \mathrm{~h}$ till the end of experiment.

Results from in situ testing are slightly higher, but comparable with those obtained from in vitro study. This might be attributed to higher complexity of cream cheese in comparison with laboratory media.

From Table 3 it is evident that panelist liked cream cheese. Cream cheese enriched with protocatechuic acid for panelist had almost the same grade as cream cheese alone. There was no statistical difference between grading cream cheese alone and cream cheese enriched with protocatechuic acid. This might be related to neutral odor of protocatechuic acid.

A membrane permeability assay to protocatechuic acid was performed, in order to evaluate if the cytoplasmic membrane breakdown in the presence of an effective concentration of this compound, leading to cell death. It was observed total nucleotide leakage from cells of $L$. monocytogenes as a function of incubation time with protocatechuic acid $(1.5 \mathrm{mg} / \mathrm{ml})$. As shown in Figure 2, optical density at 260 and $280 \mathrm{~nm}$ increased rapidly after 15 min of incubation of $L$. monocytogenes with protocatechuic acid.

The interesting activity of protocatechuic acid in cream cheese and little available information on pharmacokinetics of this compound encouraged us to investigate its pharmacokinetic profile, using the VolSurf computational procedure. Protocatechuic acid was projected on the precalculated models: skin permeability, plasmatic protein binding, volume of distribution in tissues, blood-brain barrier passage, metabolic stability, and Caco-2 cell absorption. The projection values are presented in Table 4. It is predicted that the examined compound cannot be passively transported across the intestinal epithelium; it cannot cross the blood-brain barrier or pass the skin. Also, protocatechuic acid has a moderately-low affinity to the plasma protein, and 
it is metabolically stable. Due to its low bioavailability (low distribution in tissues and permeability trough intestinal cells), protocatechuic acid might have low impact after ingestion in human organism.

\section{Discussion}

L. monocytogenes is the cause of an infection named listeriosis, which occurs mostly in elderly people, immunocompromised patients, and pregnant women (Low and Donachie, 1997). In most cases, listeriosis is associated with consumption of contaminated raw food including soft cheese (Cordano and Rocourt, 2001).

The ability of L. monocytogenes to survive a wide range of adverse conditions (acidic $\mathrm{pH}$, low temperatures, and high sodium chloride concentrations) (Farber and Peterkin, 1991) make this organism difficult to control in food. For this reason, there is a special attention of science and industry in achieving food safety by adding some natural antibacterial products without compromising the sensory and nutritional qualities of food. Herein, water extract of Veronica montana L. was explored as a source of antibacterial agents. The values of MICs and MBCs for the studied extract are much higher than those of the positive control substance antibiotics. This is not surprisingly since extracts are complex mixtures of many substances, being the concentration of each active compound certainly much lower.

A recent review of antimicrobial agents from plants reported that phenolics are the main antimicrobial chemical agents isolated from plants (Rios and Recio, 2005). It has been described that the position and number of hydroxyl groups in the phenolic acids benzoic ring is significant 
for the microbicidal activity. A higher number of hydroxyl groups results in increased activity traduced by lower inhibitory and bactericidal concentrations (Cowan, 1999).

A previous in vitro study reported that protocatechuic acid (3,4-dihydroxybenzoic acid) effectively inhibited the growth of methicillin-resistant Staphylococcus aureus, Klebsiella pneumonia, Pseudomonas aeruginosa and Acinetobacter baumannii (Liu et al., 2005). According to our findings, among all the tested bacterial strains, L. monocytogenes was the most susceptible to protocatechuic acid. Nevertheless, the most susceptible strains to crude $V$. montana extract and protocatechuic acid were different, which might be related to the presence in the extract of some inhibitory compounds or factors that masker antibacterial activity (Sastry and Rao, 1994).

Beneficial effects of addition of protocatechuic acid in cream cheese contaminated with $L$. monocytogenes were observed. This additive was able to inhibit the growth of $L$. monocytogenes in different concentrations and at different temperatures. These results are very important, taking into account the ability of $L$. monocytogenes to grow under refrigerated conditions (Swaminathan, 2001).

The leaked UV-absorbing materials from the bacterial cells treated with protocatechuic acid were measured, as an indicator of permeability alteration. If bacterial membrane is damaged to a certain extent, the release of cytoplasmic constituents of the cell (large molecules such as DNA, RNA, and other materials) can be monitored. Since these nucleotides have strong UV absorption at 260 and $280 \mathrm{~nm}$, membrane integrity can be determined through the detection of absorbance at these wavelengths. Our study indicated that protocatechuic acid could induce obvious nucleotide leakage, which is in agreement with data previously reported for the antibacterial mechanism of chlorogenic acid (Lou et al., 2011). The fact that protocatechuic acid induced damage to cell 
membrane structure and nucleotide leakage confirms it as the most likely cause of cell death. According to experimental data, it can be observed that protocatechuic acid killed contaminant bacterium L. monocytogenes by provoking irreversible permeability changes in cell membrane, leading to the lost of cytoplasm macromolecules including nucleotides.

The acute toxicity level for protocatechuic acid in laboratory animals $\left(50 \%\right.$ lethal dose $\left[\mathrm{LD}_{50}\right]>$ $800 \mathrm{mg} \mathrm{kg}^{-1}$ ) was obtained from the manufacturer. This is encouraging information since our findings suggest the use of protocatechuic acid at $1.5 \mathrm{mg} / \mathrm{ml}$ in cream cheese product. VolSurf procedure was used to investigate the possible impact of protocatechuic acid on human organism after ingestion. This program is specially designed to produce descriptors related to pharmacokinetic properties, starting from 3D molecular field maps. In the standard procedure, GRID interaction fields are calculated around the target molecules. The basic concept of VolSurf is to compress the information present in 3D grid maps into few 2D numerical descriptors, which are simple to understand and to interpret. Results previously reported following this procedure show a good correlation with the ones obtained experimentally (Djeddi et al., 2008; Karioti et al., 2011).

Antioxidant and antimicrobial properties of food additives can be applied to extend the shelf-life of food and maintain their safety, nutritional quality, functionality and palatability. The preference for natural and biologically produced antimicrobials to reduce food spoilage has become increasingly popular in comparison with those of synthetic origin which have undesirable side effects (Ebrahimabadi et al., 2010). The present study can be used to improve manufacturing processes of cream cheeses, being the product obtained more acceptable to consumers due to the use of protocatechuic acid, a natural compound. 
Overall, $V$. montana water extract and its main phenolic compound, protocatechuic acid, showed to be effective against six pathogenic bacteria using in vitro model. Furthermore, protocatechuic acid successfully preserved cream cheese by inhibiting the growth of L. monocytogenes, during the product storage period. Protocatechuic acid was positively graded by panelists for cream cheese supplementation. The major mechanism of action of this compound towards $L$. monocytognes appears to be alteration of permeability of bacteria cytoplasmic membrane. Furthermore, computational analyses showed that it is safe for human consumption. According to our results, protocatechuic acid is a promising antibacterial food preservative, showing acceptable parameters when ingested. Being a natural product present in many plant species widely consumed, we may presume that protocatechuic acid is safe for supplementation uses in food, but further clinical studies on chronic toxicity have to be conducted.

\section{Acknowledgements}

The authors are grateful to Serbian Ministry of Education and Science for financial support (grant numbers 173032, 46013). The authors also wish to express their thanks to Dr. Violeta Slavkovska for identification of the plant material.

\section{References}

Abu Ziada, M.E., Mashaly, I.A., Abd El-Monem, M., Torky, M. 2008. Economic potentialities of some aquatic plants growing in north east Nile delta, Egypt. J. Appl. Sci. 8, 13951405. 
Brull, S., Coote, P. 1999. Preservative agents in foods: mode of action and microbial resistancemechanisms. Int. J. Food Microbiol. 50, 1-17.

Condrat, D., Szabo, M.R., Radu, D., Lupea, A.X. 2009. Plant species from Angispermatophyta and Spermatophyta genus with antiradical and antimicrobial activity. Oxid. Commun. 32, 924-929.

Cordano, A.M., Rocourt, J. 2001. Occurrence of Listeria monocytogenes in food in Chile. Int. J. Food Microbiol. 70, 175-178.

Cowan, M.M. 1999. Plant products as antimicrobial agents. Clin. Microbiol. Rev. 12, 564-582.

Djeddi, S., Karioti, A., Sokovic, M., Koukoulitsa, C., Skaltsa, H. 2008. A novel sesquiterpene lactone from Centaurea pullata: Structure elucidation, antimicrobial activity, and prediction of pharmacokinetic properties. Bioorg. Med. Chem. 16, 3725-3731.

Dulger, B., Ugurlu, E. 2005. Evaluation of antimicrobial activity of some endemic Scrophulariaceae members from Turkey. Pharm. Biol. 43, 275-279.

Ebrahimabadi, A.H., Ebrahimabadi, E.H., Djafari-Bidgoli, Z., Kashi, F.J., Mazoochi, A., Batooli, H. 2010. Composition and antioxidant and antimicrobial activity of the essential oil and extracts of stachys inflate Benth from Iran. Food Chem. 119, 452-458.

Farber, J.M., Peterkin, P.I. 1991. Listeria monocytogenes, a food-borne pathogen. Microbiol. Rev. 55, 476-511.

Hanel, H., Raether, W. 1988. A more sophisticated method of determining the fungicidal effect of water-insoluble preparations with a cell harvester, using miconazole as an example. Mycoses 31, 148-154. 
Harput, U.S., Genc, Y., Khan, N., Saracoglu, I. 2011. Radical scavenging effects of different Veronica species. Rec. Nat. Prod. 5, 100-107.

Hong, D.Y., Fischer, M.A. 1998. Veronica. In Flora of China, Vol. 18. Ed. Zheng-Yi W., Raven P.H., Science Press, Beijing.

Jay, J.M. 1992. Modern Food Microbiology. Fourth Edition. NewYork: Chapman and Hall.

Karioti, A., Sokovic, M., Ciric, A., Koukoulitsa, C., Bilia, A.R., Skaltsa, H. 2011. Antimicrobial properties of Quercus ilex L. proanthocyanidin dimers and simple phenolics: evaluation of their synergistic activity with conventional antimicrobials and prediction of their pharmacokinetic profile. J. Agric. Food Chem. 59, 6412-6422.

Kim, H.Y., Lee, Y.J., Hong, K.-H., Kwon, Y.-K., Sim, K.-C., Lee, J.-Y., Cho, H.-Y., Kim, I.-S., Han, S.-B., Lee, C.-W., Shin, I.-S., Cho, J. S. 2001. Isolation of antimicrobial substances from natural products and their preservative effects. Food Sci. Biotechnol. 10, 59-71.

Küpeli, E., Harput, U.S., Varel, M., Yesilada, E., Saracogly, I. 2005. Bioassay guided isolation of iridoid glucosides with antionociceptive and anti-inflammatory activities from Veronica anagallisaquatica L. J. Ethnopharmacol. 102, 170-176.

Liu, K.S., Tsao, S.M., Yin, M.C. 2005. In vitro antibacterial activity of roselle calyx and protocatechuic acid. Phytother. Res. 19, 942-945.

Lou, Z., Wang, H., Zhu, S., Ma, C., Wang, Z. 2011. Antibacterial activity and mechanism of action of chlorogenic acid. J. Food Sci. 76, 398-403.

Low, J.C., Donachie, W. 1997, A review of Listeria monocytogenes and listeriosis. Vet. J. 153, 9-29. 
Mead, P.S., Slutsker, L., Detz, V., McCaig, L.F., Breese, J.S., Shapiro, C., Griffin, P.M., Tauxe R.V. 1999. Food related illness and dead in the United States. Emerg. Infect. Dis. 5, 607625.

Munoz-Centeno, L.M., Delgado-Sanchez, L., Santos-Vicente, M., Martinez-Ortega, M.M. 2007. Taxonomy of Veronica L. subsect. Veronica (Plantaginaceae) in the western Mediterranean. Bot. J. Linn. Soc. 155, 65-81.

Natta, L., Orapin, K., Krittika, N., Pantip, P.B. 2008. Essential oil from zingi beraceae for anti food borne bacteria. Int. Food Res. J. 15, 337-346.

Reis, F.S., Stojković, D., Soković, M., Glamočlija, J., Cirić, A., Barros, L., Ferreira, I.C.F.R. 2012. Chemical characterization of Agaricus bohusii, antioxidant potential and antifungal preserving properties when incorporated in cream cheese. Food Res. Int. 48, 620-626.

Rios, J.L., Recio, M.C. 2005. Medicinal plants and antimicrobial activity. J. Ethnopharmacol. $100,80-84$.

Sastry, V.M.V.S., Rao, G.R.K. 1994. Antibacterial substances from marine algae: Successive extraction using benzene, chloroform and methanol. Bot. Mar. 37, 357-360.

Scalbert, A. 1991. Antimicrobial properties of tannins. Phytochem. 30, 3875-3883.

Sorheim, O., Kropf, D.H., Hunt, M.C., Karwoski, M.T., Warren, K.E. 1996. Effects of modified gas atmosphere packaging on pork loin colour, display life and drip loss. Meat Sci. 43, 203-212.

Swaminathan, B. 2001. Listeria monocytogenes, p. 383-409. In M. P. Doyle, L. R. Beuchat, and T. J. Montville (ed.), Food microbiology: fundamentals and frontiers. ASM Press, Washington, DC. 
Tang, Y.L., Shi, Y.H., Zhao, W., Hao, G., Le G.W. 2008, Insertion mode of a novel anionic antimicrobial peptide MDpep5 (Val-Glu-Ser-Trp-Val) from Chinese traditional edible larvae of housefly and its effect on surface potential of bacterial membrane. J. Pharm. Biomed. 48, 1187-1194.

Taskova, R.M., Kokubin, T., Ryan, K.G., Gamock-Jones, P.J., Jensen, S.R. 2010. Phenylethanoid and iridoid glycosides in the New Zealand Snow Hebes (Veronica, Plantaginaceae). Chem. Pharm. Bull. 58, 703-711.

Tilford, L.G. 1997. Edible and medicinal plants of the West, 1st edition. Mountain Press Publishing Company, Missoula, Montana.

Tiwari, B.K., O'Donnell, C.P., Cullen, P.J. 2009. Effect of non thermal processing technologies on the anthocyanin content of fruit juices. Trends Food Sci. Technol. 20, 137-145. 
Table 1. Antibacterial activity of Veronica montana water extract and main phenolic compound - protocatechuic acid (mg/ml).

\begin{tabular}{|c|c|c|c|c|c|c|c|c|}
\hline & & S. aureus & B. cereus & M. flavus & L. monocytogenes & P. aeruginosa & E. coli & E. cloacae \\
\hline \multirow{3}{*}{ Water extract } & MIC & $7.50 \pm 0.01$ & $25.50 \pm 0.01$ & $7.50 \pm 0.01$ & $7.50 \pm 0.00$ & $22.50 \pm 0.01$ & $15.00 \pm 0.02$ & $7.50 \pm 0.02$ \\
\hline & & & & & & & & \\
\hline & $\mathrm{MBC}$ & $7.50 \pm 0.02$ & $45.50 \pm 0.01$ & $15.00 \pm 0.02$ & $15.00 \pm 0.00$ & $45.00 \pm 0.02$ & $15.00 \pm 0.01$ & $15.50 \pm 0.02$ \\
\hline \multirow{3}{*}{ Protocatechuic acid } & MIC & $3.00 \pm 0.00$ & $3.00 \pm 0.00$ & $3.00 \pm 0.01$ & $0.75 \pm 0.00$ & $3.00 \pm 0.00$ & $3.00 \pm 0.01$ & $3.00 \pm 0.01$ \\
\hline & & & & & & & & \\
\hline & $\mathrm{MBC}$ & $3.00 \pm 0.00$ & $3.00 \pm 0.00$ & $3.00 \pm 0.01$ & $1.00 \pm 0.00$ & $3.00 \pm 0.00$ & $3.00 \pm 0.01$ & $3.00 \pm 0.00$ \\
\hline \multirow{3}{*}{ Streptomycin } & MIC & $0.03 \pm 0.00$ & $0.01 \pm 0.00$ & $0.03 \pm 0.00$ & $0.01 \pm 0.00$ & $0.05 \pm 0.01$ & $0.10 \pm 0.01$ & $0.05 \pm 0.01$ \\
\hline & & & & & & & & \\
\hline & $\mathrm{MBC}$ & $0.06 \pm 0.01$ & $0.03 \pm 0.01$ & $0.06 \pm 0.01$ & $0.03 \pm 0.00$ & $0.10 \pm 0.01$ & $0.20 \pm 0.01$ & $0.10 \pm 0.01$ \\
\hline
\end{tabular}

The results are expressed as mean \pm standard deviation. MIC- minimum inhibitory concentration; MBC- minimum bactericidal concentration. 
Table 2. Growth inhibition percentage of Listeria monocytogenes with protocatechuic acid in cream cheese stored at room temperature and in refrigerator.

\begin{tabular}{lcccccc}
\hline Conc./ & \multicolumn{2}{c}{$0.75 \mathrm{mg} / \mathrm{ml}$} & \multicolumn{2}{c}{$1.5 \mathrm{mg} / \mathrm{ml}$} & \multicolumn{2}{c}{$3.0 \mathrm{mg} / \mathrm{ml}$} \\
Temp & $+4^{\circ} \mathrm{C}$ & $+25^{\circ} \mathrm{C}$ & $+4^{\circ} \mathrm{C}$ & $+25^{\circ} \mathrm{C}$ & $+4{ }^{\circ} \mathrm{C}$ & $+25^{\circ} \mathrm{C}$ \\
\hline $0 \mathrm{~h}$ & $0.00 \pm 0.00$ & $0.00 \pm 0.00$ & $0.00 \pm 0.00$ & $0.00 \pm 0.00$ & $0.00 \pm 0.00$ & $0.00 \pm 0.00$ \\
& & & & & & \\
$24 \mathrm{~h}$ & $97.34 \pm 1.90$ & $0.00 \pm 0.00$ & $100 \pm 0.00$ & $84.36 \pm 8.30$ & $100 \pm 0.00$ & $100 \pm 0.00$ \\
$48 \mathrm{~h}$ & $95.52 \pm 3.40$ & $0.00 \pm 0.00$ & $100 \pm 0.00$ & $14.40 \pm 3.40$ & $100 \pm 0.00$ & $100 \pm 0.00$ \\
$72 \mathrm{~h}$ & $94.14 \pm 4.70$ & $0.00 \pm 0.00$ & $100 \pm 0.00$ & $0.00 \pm 0.00$ & $100 \pm 0.00$ & $100 \pm 0.00$ \\
\hline
\end{tabular}

The results are expressed as mean \pm standard deviation. 
Table 3. Acceptability scores given by panelist for cream cheese and cream cheese with protocatechuic acid (PA).

\begin{tabular}{lcc}
\hline & Cream cheese & Cream cheese + PA \\
\cline { 2 - 3 } Acceptability $^{*}$ & $4.1 \pm 0.9$ & $4.2 \pm 0.8$ \\
\hline
\end{tabular}

The results are expressed as the average of all grades \pm SD.

$1=$ extremely dislike, 2 = dislike, $3=$ neither like nor dislike, $4=$ like; $5=$ extremely like. 
Table 4. Predicted pharmacokinetic properties of protocatechuic acid (PA)

\begin{tabular}{ccccccc}
\hline & Skin $^{\mathrm{a}}$ & $\mathrm{PB}^{\mathrm{b}}$ & $\mathrm{VD}^{\mathrm{c}}$ & $\mathrm{BBB}^{\mathrm{d}}$ & MetStab $^{\mathrm{e}}$ & Caco2 $^{\mathrm{f}}$ \\
\hline PA & -3.99 & 30.09 & -0.48 & -1.75 & 100 & -0.32 \\
\hline
\end{tabular}

${ }^{a}$ Skin permeability expressed as $\mathrm{cm} / \mathrm{h}$; ${ }^{\mathrm{b}}$ protein binding expressed as $\%,{ }^{\mathrm{c}}$ volume of distribution expressed as logarithmic value from $\mathrm{L} \mathrm{kg}^{-1}$; ${ }^{\mathrm{d}} \log$ blood brain barrier distribution; ${ }^{\mathrm{e}}$ percentage of the remaining compound after incubation with human CYP3A4 enzyme; ${ }^{\mathrm{f}} \mathrm{Caco} 2$ cell permeation model, quantitative value (-1 low if any ability to penetrate epithelial cells, 1 penetrating epithelial cells). 


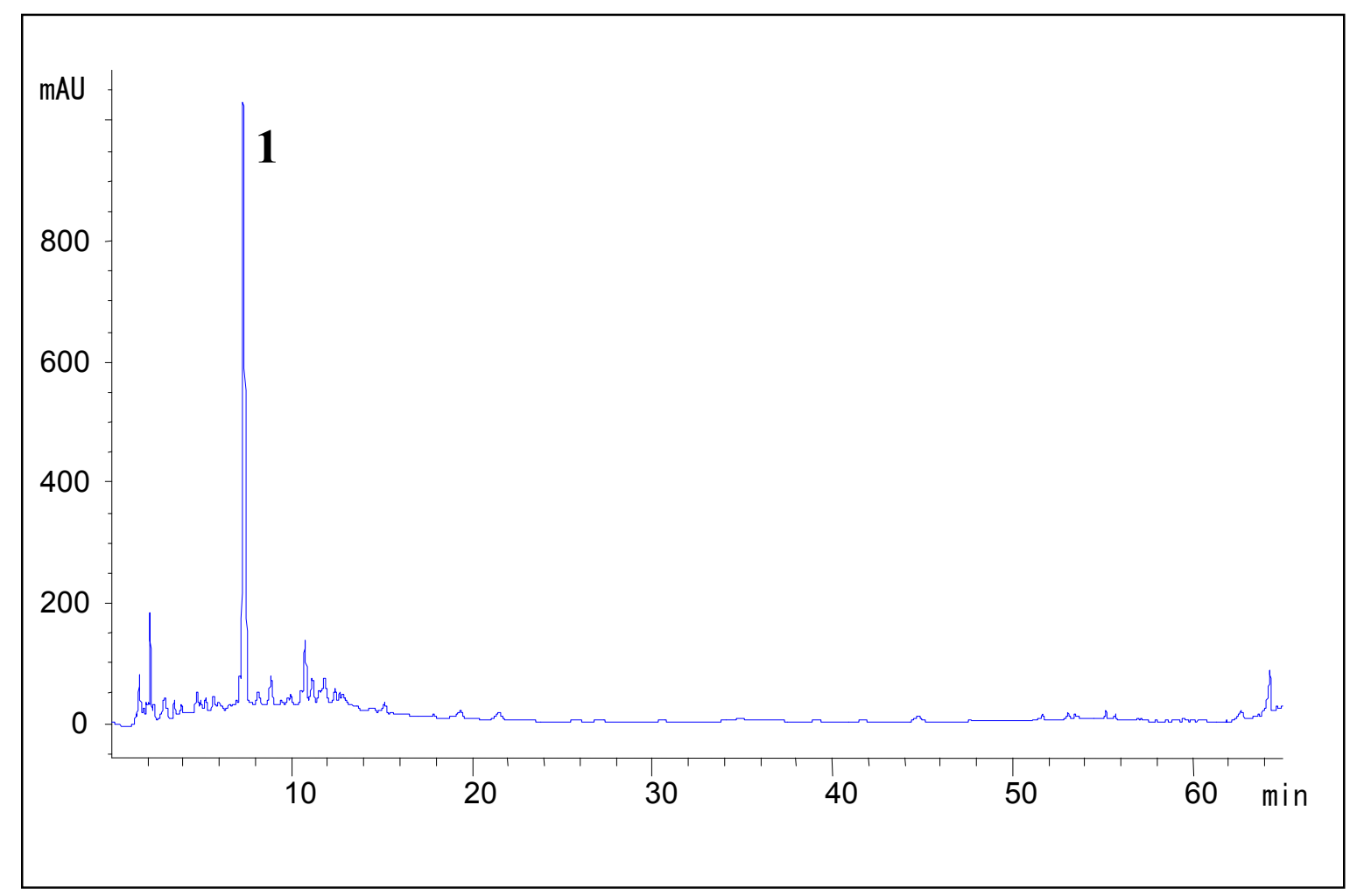

Figure 1. HPLC chromatogram at $204 \mathrm{~nm}$ of Veronica montana water extract. Peak identification: (1) protocatechuic acid. 


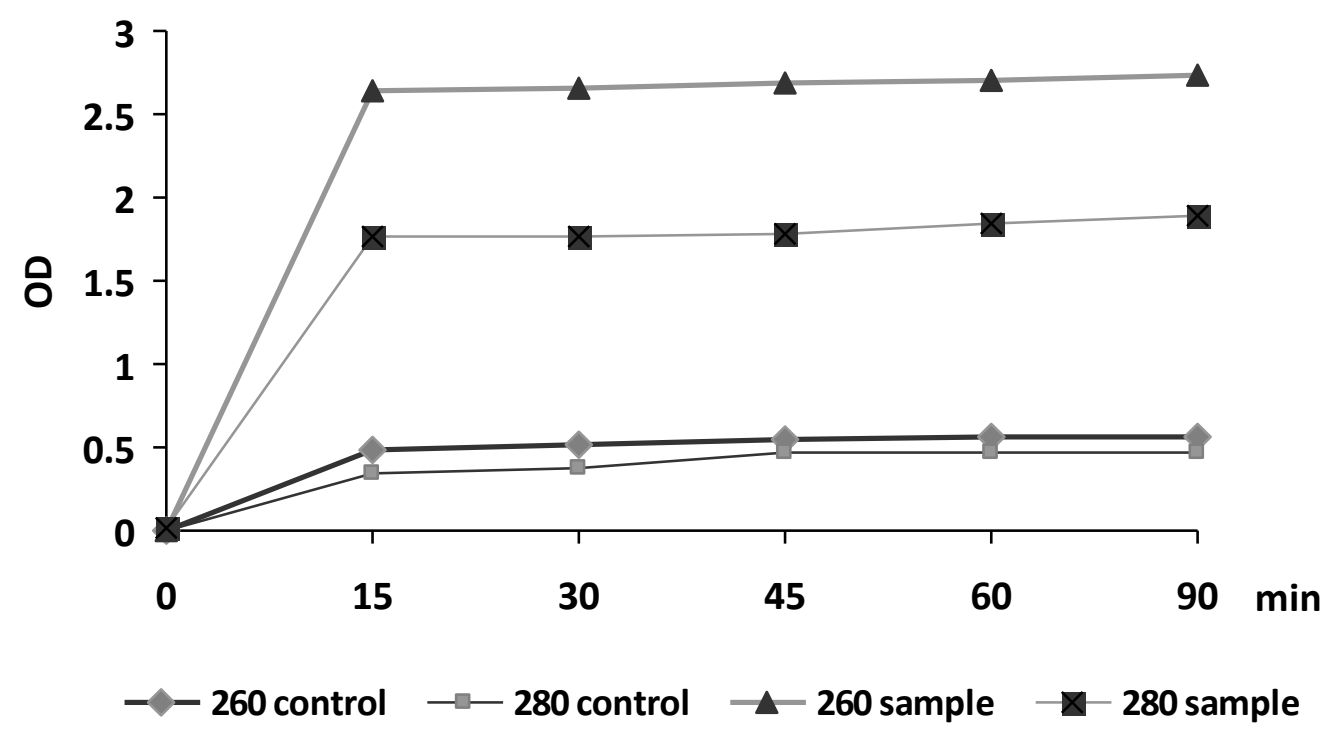

Figure 2. Total nucleotide leakage recorded by optical density at 260 and $280 \mathrm{~nm}$ from Listeria monocytogenes cells treated by protocatechuic acid. 